\title{
Are people with epilepsy using eHealth-tools?
}

Citation for published version (APA):

Leenen, L., Wijnen, B. F. M., de Kinderen, R. J. A., van Heugten, C. M., Evers, S. M. A. A., \& Majoie, M. H. J. M. (2016). Are people with epilepsy using eHealth-tools? Epilepsy \& Behavior, 64(Pt A), 268-272. https://doi.org/10.1016/j.yebeh.2016.08.007

Document status and date:

Published: 01/11/2016

DOI:

10.1016/j.yebeh.2016.08.007

Document Version:

Publisher's PDF, also known as Version of record

Document license:

Taverne

\section{Please check the document version of this publication:}

- A submitted manuscript is the version of the article upon submission and before peer-review. There can be important differences between the submitted version and the official published version of record.

People interested in the research are advised to contact the author for the final version of the publication, or visit the DOI to the publisher's website.

- The final author version and the galley proof are versions of the publication after peer review.

- The final published version features the final layout of the paper including the volume, issue and page numbers.

Link to publication

\footnotetext{
General rights rights.

- You may freely distribute the URL identifying the publication in the public portal. please follow below link for the End User Agreement:

www.umlib.nl/taverne-license

Take down policy

If you believe that this document breaches copyright please contact us at:

repository@maastrichtuniversity.nl

providing details and we will investigate your claim.
}

Copyright and moral rights for the publications made accessible in the public portal are retained by the authors and/or other copyright owners and it is a condition of accessing publications that users recognise and abide by the legal requirements associated with these

- Users may download and print one copy of any publication from the public portal for the purpose of private study or research.

- You may not further distribute the material or use it for any profit-making activity or commercial gain

If the publication is distributed under the terms of Article $25 \mathrm{fa}$ of the Dutch Copyright Act, indicated by the "Taverne" license above, 


\title{
Are people with epilepsy using eHealth-tools?
}

\author{
Loes A.M. Leenen ${ }^{\text {a,b,c,d,* }}$, Ben F.M. Wijnen ${ }^{\text {a,b,c }}$, Reina J.A. de Kinderen ${ }^{\text {a,b,c }}$, Caroline M. van Heugten ${ }^{\text {e,f }}$, \\ Silvia M.A.A. Evers ${ }^{\mathrm{a}, \mathrm{b}, \mathrm{g}}$, Marian H.J.M. Majoie ${ }^{\mathrm{c}, \mathrm{d}, \mathrm{e}, \mathrm{h}}$ \\ ${ }^{a}$ CAPHRI School for Public Health and Primary Care, Maastricht University, Maastricht, The Netherlands \\ b Department of Health Services Research, Maastricht University, Maastricht, The Netherlands \\ c Department of Research \& Development, Epilepsy Centre Kempenhaeghe, Heeze, The Netherlands \\ d Department of Neurology, Academic Centre for Epileptology, Epilepsy Centre Kempenhaeghe E Maastricht University Medical Centre, The Netherlands \\ e MHENS, School for Mental Health and Neuroscience, Department of Psychiatry and Neuropsychology, Maastricht University Medical Centre, Maastricht, The Netherlands \\ ${ }^{\mathrm{f}}$ Department of Neuropsychology and Psychopharmacology, Maastricht University, Maastricht, The Netherlands \\ g Trimbos Institute, Netherlands Institute of Mental Health and Addiction, Utrecht, The Netherlands \\ h School of Health Professions Education, Faculty of Health, Medicine and Life Sciences, Maastricht UMC +, The Netherlands
}

\section{A R T I C L E I N F O}

\section{Article history:}

Received 26 May 2016

Revised 4 August 2016

Accepted 5 August 2016

Available online 24 October 2016

\section{Keywords:}

Epilepsy

EHealth

EHealth-tools

Self-management

Self-monitoring

Shared decision

\begin{abstract}
A B S T R A C T
Introduction: Self-management for people with epilepsy (PWE) should lead to shared decision-making and thus to adherence to the treatment plan. eHealth is an important way of supporting PWE in their self-management. Method: In this survey, we used a mixed method to explore the following: 1) which factors were monitored by PWE and how (using pen and paper or eHealth-tools), 2) how many PWE own a computer or smartphone, and 3) how do they perceive the use of eHealth. A consecutive series of 1000 PWE attending the outpatient clinic of a tertiary epilepsy center were asked to fill in a questionnaire.

Results: In comparison with the general population, fewer PWE owned a computer or smartphone. They were, however, more likely to self-monitor their health than other patients suffering from a chronic condition. Although PWE did not use eHealth-tools often, they perceived it as a user-friendly tool, promoting health behavior as well as adherence. On the other hand, problems with privacy and the perception that not everyone is able to use eHealth were considered as disadvantages by PWE. Promoting self-care was perceived as both an advantage and a disadvantage. It was seen as an advantage when PWE mentioned the option of eHealth-tools in order to gain insight into one's epilepsy. At the same time, it was seen as a disadvantage because it confronts PWE with their disease, which causes emotional stress.

Conclusion: The high level of self-monitoring combined with a low usage of eHealth-tools seems to indicate that there is a need for a more tailored approach to stimulate the use of eHealth-tools by PWE. Further research should focus on this aspect, e.g., what PWE need in order to make more use of eHealth-tools in their self-care.
\end{abstract}

(c) 2016 Elsevier Inc. All rights reserved.

\section{Introduction}

Epilepsy is a disorder of the brain characterized by recurrent seizures, which result from sudden electrical discharges in groups of brain cells. These discharges result in a variety of clinical manifestations, depending on where they occur in the brain [1].

For the treatment of people with a chronic condition, such as epilepsy, self-management is believed to be an important factor in

\footnotetext{
* Corresponding author at: Academic Centre for Epileptology Kempenhaeghe, Sterkselseweg 65, P.O. Box 61, 5590AB Heeze, The Netherlands.

E-mail addresses: leenenl@kempenhaeghe.nl (L.A.M. Leenen), b.wijnen@maastrichtuniversity.nl (B.F.M.Wijnen), reina.dekinderen@maastrichtuniversity.nl (R.J.A. de Kinderen), c.vanheugten@maastrichtuniversity.nl (C.M. van Heugten), s.evers@maastrichtuniversity.nl (S.M.A.A. Evers), majoiem@kempenhaeghe.nl (M.H.J.M. Majoie).
}

sustaining or increasing quality of life and quality of care [2]. Selfmanagement refers to the ability of patients to cope with their chronic condition, eventually aiming to maximize quality of life [3].

In order to manage their life, people with epilepsy (PWE) have to become knowledgeable about their disease and the factors influencing the disease and treatment. Furthermore, they have to adhere to treatment and lifestyle regimens and to cope with the psychosocial consequences of having this chronic condition [4,5].

The tools to support self-management for people with a chronic condition range from individual and group training sessions to (smart)phone applications (often regarded as "apps") and websites [6]. During the past decade, the latter two forms of delivering information have become more popular as shown by the increasing amount of online information, online health services, and online self-help programs, often regarded as eHealth. eHealth is defined as the use of information communication technologies (ICT) to improve or enable health and 
health care [6]. It often incorporates wireless, mobile electronic tools (eHealth-tools) [6].

In order to support individuals with a chronic condition in their selfmanagement, eHealth-tools need to be more than merely a source of information $[7,8]$. Some examples of tools that offer more are the e-medication feedback tool [9] and e-diaries [10]. Both applications have been shown to improve adherence.

eHealth is an easily accessible and convenient way of reaching a large target group and, more importantly, potentially leading to improved health outcomes $[11,12]$. For this reason, the Dutch government has incorporated the development and application of eHealth in their objectives to establish quality of health care [13]. In addition, the Dutch government is trying to use eHealth as a way of controlling health costs in an aging society [2]. In 2015, the government stated that, within five years, $80 \%$ of the patients with a chronic condition should have access to their medical records, preferably using mobile- or internetbased applications. Seventy-five percent of these patients should have the option and be able to self-monitor their condition using eHealth [8]. The proportion of people with a chronic condition already monitoring their disorder in 2015 was $40 \%$. Ten percent were using a computer and $3 \%$ a smartphone.

Currently, several eHealth-tools are available for PWE, such as "My seizure diary" (www.Myseizurediary.com) and "Seizure tracker" (www.seizuretracker.com). These eHealth-tools are designed so that PWE can register seizure frequency and other epilepsy-related factors, in order to provide data that can support the management of epilepsy [14]. Previous studies have shown that eHealth is able to improve health outcomes in other chronic conditions $[15,16]$, including epilepsy [17]; this study showed an improvement in selfmanagement and self-efficacy outcomes of an online self-management program.

It has been shown, however, that not every group of patients with a chronic condition benefits equally from the growing body of eHealthtools $[18,19]$. This is due to several barriers to using eHealth-tools to their full potential, such as the lack of access to hardware (e.g., personal computer or laptop, smartphone, or tablet) and the lack of skills required to use eHealth-tools properly [20,21].

In a recent study by the US Center for Disease Control, the authors suggested that the use of easy-to-access resources and eHealth-tools might help PWE to optimize their self-management and eventually improve their quality of life [22].

There is, however, no body of evidence regarding the effectiveness of eHealth-tools for PWE.

The main purpose of this study was, therefore, to explore whether PWE have access to hardware and if they perceive eHealth-tools as useable in their (self)-care.

This study focused on three main topics:

1) Which events are self-monitored and which tools do PWE use?

2) In comparison with the general Dutch population, how many PWE possess hardware that can be used for eHealth?

3) What are the advantages and disadvantages of eHealth as perceived by PWE - both users and nonusers - of eHealth-tools?

\section{Methods}

\subsection{Population}

This study was conducted among patients diagnosed with epilepsy treated at Kempenhaeghe, a tertiary epilepsy center serving the southern part of The Netherlands.

A consecutive series of 1000 patients who visited the Kempenhaeghe outpatient clinic in the first trimester of 2013 were contacted to participate in the study in order to obtain a representative sample. Respondents were either adults with epilepsy or parents/caregivers serving as proxy for their child with epilepsy and/or for people with cognitive deficits associated with their epilepsy. In the case of the latter respondents, the cover letter was addressed to the parents or carers.

\subsection{Procedure and survey}

The survey was conducted using a self-completion 14-item questionnaire (Appendix 1), sent with a cover letter explaining the reasons for the study and asking the respondent or parent(s) by proxy to fill it in. After 8 weeks, a reminder was sent. Respondents consented to participate by returning the questionnaire. The local medical ethics review board of the Centre for Epilepsy Kempenhaeghe approved this study.

The survey covered the following topics:

demographic information: including age, gender, and who completed the questionnaire;

use and content of self-monitoring tool: which events were selfmonitored, the reason for self-monitoring these events, and whether respondents used eHealth-tools or a more traditional way (e.g., using pencil and paper) of collecting data;

possession of hardware: whether or not respondents owned hardware such as a computer, smartphone, or tablet; and perceived advantages and disadvantages of eHealth: two open-ended questions.

\subsection{Analyses}

All analyses were conducted in SPSS Version 21. Descriptive statistics were used to summarize important variables. Pearson Chi square test was used to determine statistical differences between binary variables (e.g., gender) and logistic regression to determine the effect of categorical variables (i.e., 4 age groups: 12-24 y, 25-44 y, 45-64 y, and 65-100 y) on binary outcome measures (i.e., possession of: smartphone $y / n$, computer $y / n$, and tablet $y / n$ ). Age groups were defined according to the categorization of the Statistics Netherlands [23].

Analyses of the open-ended questions were carried out using a qualitative method. The answers to these open-ended questions were labeled according to the description used in the systematic review of Interactive Health applications for people with chronic conditions by Murray et al. [7]. The following categories were defined: 1) relaying information; 2) enabling shared decision-making; 3) promoting health behaviors e.g., using medication reminders or alarms; 4) promoting peer information exchange and support; 5) promoting self-care e.g., using a seizure diary and scoring seizure-provoking factors; 7) managing demands for health services; 8) equity (equity is the accessibility by means of eHealth to services, health care, and health outcome); 9) quality criteria such as privacy, etc.; 10) other (this category was added to accommodate the responses that could not be assigned to one of the above categories). In addition to this framework, user-friendliness was added as an extra category (11), because it was frequently mentioned by the respondents.

\section{Results}

A total of 571 respondents (57\%) completed the questionnaire, 284 of whom were female (50.7\%). In the case of 11 respondents, gender was not recorded.

The mean age was $38.3 \mathrm{y}$ ( $\mathrm{sd}=18.5 \mathrm{y}$ ), The survey was completed by PWE ( $\mathrm{n}=259$ ), in 8 cases by the partners and in 175 instances by parents/caregivers; for 129 surveys, it was not known who completed the questionnaire. 


\subsection{Use and content of self-monitoring tools}

Almost two-thirds (62.2\%) of the respondents monitor their seizures in some way, and approximately half of the respondents (52.7\%) used a kind of memory aid for taking antiepileptic drugs, such as a medication box $(18 \%)$ or alarm on their phone $(14 \%)$.

Eleven percent of the respondents have downloaded a health app (on a mobile device) in order to facilitate their self-monitoring.

As presented in Table 1, more than half of the respondents $(n=272)$ monitor other factors as well. Change of medication (66\%), side effects (43\%), and use of (36\%) emergency medication were the most mentioned medication-related factors. Several other factors were also monitored, for instance, stress factors (38\%), diurnal rhythm (19\%), and menstrual cycle (17\%).

The three most important reasons respondents indicated for self-monitoring were because that: 1 ) it provides insight into their seizure pattern $(91.3 \%), 2$ ) it helps to find factors influencing their seizures (87.6\%), and 3) they had been asked by a neurologist ( $87.3 \%$ ).

Table 2 lists the tools used to self-monitor seizure frequency; i.e., this is usually a paper diary (43\%) rather than an eHealth-tool, such as a digital diary (16\%). With regard to an aid to assist medication intake, the traditional tools, such as a medication box (52\%), are used more often compared with eHealth-tools (14\%).

\subsection{Possession of hardware}

Of the respondents, $82 \%$ owns a computer and $39 \%$ a smartphone.

No significant differences were found between males and females regarding access to any of these eHealth-tools.

Patients aged 12-24 did not significantly differ from patients aged 25-44 regarding the use of a personal computer (PC) or laptop, smartphone, or tablet.

However, patients aged 45-64 and patients aged over 65 used a PC or laptop ( $\mathrm{p}=.006 ; \mathrm{p}=.000)$, smartphone $(\mathrm{p}=.000 ; \mathrm{p}=.000)$, or tablet $(\mathrm{p}=.012 ; \mathrm{p}=.006)$ significantly less often.

\subsection{Advantages and/or disadvantages of using eHealth-tools}

One hundred sixty-six respondents mentioned one or two advantages; disadvantages were mentioned by 138 respondents. Some factors were mentioned as an advantage by part of the group while others regarded this as a disadvantage; for instance, less stress is mentioned as an advantage and more stress as a disadvantage of using eHealth.

An impression of mentioned quotes per categories is given in Appendix 2.

Table 1

Overview of events self-monitored by respondents.

\begin{tabular}{ll}
\hline $\begin{array}{l}\text { Events self-monitored } \\
\mathrm{n}(\%)\end{array}$ & \\
\hline Seizure frequency & $354(62 \%)$ \\
Medication intake & $297(52 \%)$ \\
Other events monitored & $272(48 \%)$ \\
Medication-related events & \\
Medication change & $179(66 \%)$ \\
Side effects & $118(43 \%)$ \\
Frequency of using emergency medication & $100(36 \%)$ \\
Medication used for emergency reasons & $65(24 \%)$ \\
Forgotten AED intake & $81(31 \%)$ \\
Intake of contraceptives & $10(4 \%)$ \\
Distribution of other monitored events & \\
Stress factors & $102(38 \%)$ \\
Diurnal rhythm & $53(19 \%)$ \\
Menstrual cycle & $45(17 \%)$ \\
Alcohol use & $16(6 \%)$ \\
\hline
\end{tabular}

Total $>100 \%$, because respondents could monitor more than one event.
Table 2

Use of tools for self-monitoring and taking medication by people with epilepsy.

\begin{tabular}{ll}
\hline Tools to self-monitor seizure frequency & $\mathrm{N}(\%)$ \\
\hline eHealth-tool & \\
$\quad$ Digital diary & \\
Other tools & $247(43 \%)$ \\
$\quad$ Paper diary & $16(3 \%)$ \\
Other & $24(5 \%)$ \\
Missing & $194(33 \%)$ \\
None & $=2)$ and memory $(\mathrm{n}=5)$ \\
Other stands for: family or carers $(\mathrm{n}=9) ;$ camera $(\mathrm{n})$ & \\
& $\mathrm{N}(\%)$ \\
Tools to assist in taking medication & $79(14 \%)$ \\
\hline eHealth-tool & $103(18 \%)$ \\
$\quad$ Alert on phone & $45(8 \%)$ \\
Other aids & $55(10 \%)$ \\
$\quad$ Medication box & $21(5 \%)$ \\
Drug dosage package & $24(4 \%)$ \\
Notification by family or carers & $244(43 \%)$ \\
Other & \\
Missing & \\
None & \\
Other stands for: alarm watches/clocks $(\mathrm{n}=7)$, daily routine $(\mathrm{n}=12)$, visual aid \\
( $\mathrm{n}=2)$
\end{tabular}

User-friendliness ( $n=64)$, promoting self-care $(n=61)$, and promoting health behavior $(n=53)$ were the three largest categories of advantages (A). For disadvantages (D), the largest categories were the following: equity ( $\mathrm{n}=48$ ); promoting self-care e.g., using a seizure diary and scoring seizure-provoking factors $(\mathrm{n}=38)$; and quality criteria, e.g., privacy and user-friendliness $(n=34)$.

An overview of all categories is shown in Fig. 1.

\section{Discussion}

The aim of this study was to explore whether PWE had access to eHealth-tools and whether they perceived eHealth as a useable aid in their self-care. This study focused on three topics; each of these will be discussed separately.

Of note, internet penetration in Netherlands in the study period (2013) was 94\% (www.internetlivestats.com/internet-users/ netherlands/) and, hence, unlikely to have affected the accuracy of the results.

\subsection{Use and content of self-monitoring tools}

A majority of the PWE self-monitor their condition by keeping track of their seizures (62\%) or using a medication reminder (53\%). In addition, $48 \%$ of the respondents monitor on average two to three other events. Most monitoring is not, however, performed with eHealth-tools. People with other chronic conditions monitor their condition less frequently (40\%), and the percentage of eHealth-tool users in this group is smaller (10\% use a computer and $3 \%$ use a smartphone) [8] than in the group of PWE.

Reasons for the differences between the two groups could be (1) that the respondents in our study were younger (mean age: $38.3 \mathrm{y}$ ) than those with other chronic conditions (mean age $>60 \mathrm{y}$ ) or (2) that epilepsy is a chronic condition often with onset early in life, and so PWE learn earlier to keep track of events influencing their condition (e.g., self-monitoring).

In spite of evidence that eHealth-tools such as e-medication feedback [9] and e-diaries [10] improve adherence, our study shows that most respondents did not use these eHealth-tools and, therefore, could not benefit from them. A reason for not using eHealth-tools might be that the abovementioned tools "Seizure tracker" and "My seizure diary" are not available in Dutch. 


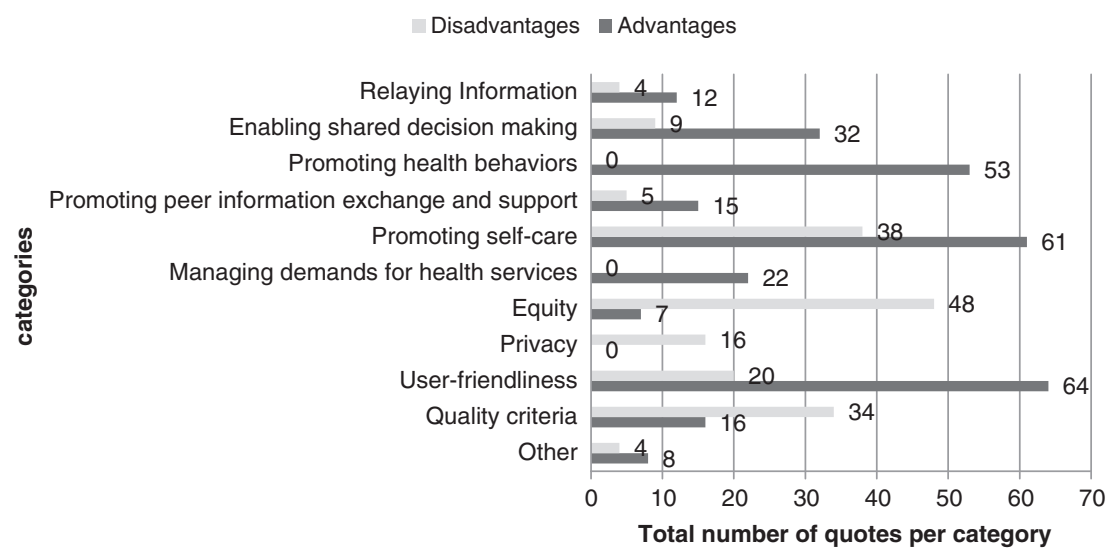

Fig. 1. Perceived (dis)advantages.

\subsection{Possession of hardware}

We compared our data with data gathered in the same year (2013) from the general population.

It seems that a lower percentage of PWE own a computer or smartphone than the general population (i.e., computer $82 \%$ vs $95 \%$ and smartphone $37 \%$ vs $72 \%$ ) [23]. However, no differences were found between males and females in this regard, in line with findings in the Dutch population [23].

In our study population, the use of a computer in the four age groups and the use of a smartphone or tablet showed trends similar to the general Dutch population; e.g., younger people are more likely to own a computer, smartphone, or tablet than older people [23].

However, it has been shown that, in the general population, it is mainly the oldest age group who do not own a computer or smartphone [23], whereas in the present study, the lower percentage is observed in a younger age-group: 45-64 y.

\subsection{Advantages and/or disadvantages of using eHealth-tools}

Promoting self-care was the most mentioned disadvantage and the second most mentioned advantage. Those who called this an advantage said in most cases that it could give them insight into their seizure frequency and related events in a way that prepared them for the consultation with the neurologist. This supports the idea that eHealthtools can be an advantage in the process of shared decision-making $[3,13]$; this was also one of the largest categories in our study. In contrast, those who called promoting self-care a disadvantage focused more on emotions, such as confrontation with their disease, emotional stress, or defining them as patients. The fact that equity was seen as an important disadvantage suggests that people are concerned that not everyone is able to work with eHealth-tools.

eHealth-tools can be helpful for PWE in self-management, including monitoring and managing symptoms (self-care and adherence to treatment and lifestyle regimens (health behavior)) [3-5]. On the one hand, some respondents seem to agree with this statement by referring to the promotion of self-care and health behavior as an advantage of eHealth [15-17]. On the other hand, the disadvantages mentioned (equity, perceived lack of privacy) seem to indicate that some PWE perceive problems in their ability to use eHealth-tools and also that they perceive a negative effect on their psychosocial wellbeing. It is, however, possible that many PWE have no clear picture of what eHealth is or what eHealth-tools can do for them. This phenomenon was also observed in the annual eHealth-monitor report by the Dutch government. Respondents in this research study gave contradictory answers: the same respondent answered 'yes' when asked if they accessed their Personal Medical Record digitally and 'no' to having access to the internet [8].

\subsection{Limitations of this study}

This study is prone to several limitations. Firstly, the population is relatively heterogeneous, being comprised of respondents with different types of epilepsy. Hence, certain factors, such as severity of disease or cognitive deficits, may have influenced the use of and intention to use eHealth. Secondly, although we achieved a respectable response rate of $57.1 \%$, it is possible that there is a selection-bias within our sample, as reasons for not responding are not known. Thirdly, the questionnaire was relatively short and lacked some possible important factors, as income and educational level, which have been proven relevant in other studies [18,24]. Fourthly, as this was a cross-sectional design, we are unable to view trends over time.

\section{Conclusion}

In this study, the proportion of PWE who own a computer or smartphone is lower than in the Dutch population. People with epilepsy monitor their condition and several events influencing it, but they tend to use pen and paper most frequently, rather than eHealth-tools. Issues which PWE perceive as being (dis)advantages of using eHealth or eHealth-tools are diverse and sometimes contradictory.

The advantages mentioned - supporting PWE in their self-care or enabling them to make shared decisions - are both important factors in stimulating self-management. Self-management is a key component in focusing on quality of life and care for those with chronic conditions such as epilepsy. It is, therefore, important to focus on methods to implement eHealth tools for these patients.

In light of the disadvantages mentioned, we suggest a patienttailored approach in order to solve the perceived problems. This could improve the implementation of eHealth-tools for self-monitoring by PWE.

Knowing more about the perception of eHealth by PWE makes it easier to develop strategies to support them in using eHealth-tools in their self-care. Further structured research is, therefore, necessary and should involve PWE in developing these eHealth-tools.

Supplementary data to this article can be found online at http://dx. doi.org/10.1016/j.yebeh.2016.08.007.

\section{Conflict of interest}

The authors declare that there is no conflict of interest.

\section{References}

[1] Epilepsy fact sheet N*999. World Health Organisation; 2015.

[2] Raad voor de Volksgezondheid (RVZ). Gezondheid 2.0.; 2010.

[3] Ouwens M, van der Burg S, Faber M, van der Weijden T. Shared decision making \& self management. Scientific Institute for Quality of Healthcare; 2012. 
[4] Groenewegen A, Tofighy A, Ryvlin P, Steinhoff BJ, Dedeken P. Measures for improving treatment outcomes for patients with epilepsy - results from a large multinational patient-physician survey. Epilepsy Behav 2014;34:58-67.

[5] Barlow J, Wright C, Sheasby J, Turner A, Hainsworth J. Self-management approaches for people with chronic conditions: a review. Patient Educ Couns 2002;48:177-87.

[6] Krijgsman J, Klein WG. Whitepaper Ordening in de wereld van eHealth. Nictiz; 2012.

[7] Murray E, Burns J, See Tai S, Lai R, Nazareth I. Interactive Health Communication Applications for people with chronic disease. Cochrane Database Syst Rev 2005.

[8] Krijgsman J, et al. 'Dan kan ik er misschien zelf iets aan doen': tussenrapportage eHealth-monitor 2015; 2015.

[9] Demonceau J, et al. Identification and assessment of adherence-enhancing interventions in studies assessing medication adherence through electronically compiled drug dosing histories: a systematic literature review and meta-analysis. Drugs 2013;73:545-62.

[10] Fisher RS, et al. Seizure diaries for clinical research and practice: limitations and future prospects. Epilepsy Behav 2012;24:304-10.

[11] Eland-de Kok P, van Os-Medendorp H, Vergouwe-Meijer A, Bruijnzeel-Koomen C, Ros W. A systematic review of the effects of e-health on chronically ill patients. J Clin Nurs 2011;20:2997-3010.

[12] Notenboom A, Blankers I, Goudriaan R, Groot W. E-health en zelfmanagement: een panacee voor arbeidstekorten en kostenoverschrijdingen in de zorg? American Chamber of Commerce (opdrachtgever); 2012.

[13] Raad voor de Volksgezondheid (RVZ). De participerende patiënt. Raad voor de Volgsgezondheid en Zorg; 2013.

[14] Shegog R, et al. Managing epilepsy well: emerging e-tools for epilepsy selfmanagement. Epilepsy Behav 2013;29:133-40.
[15] Timmer S. eHealth-interventies. eHealth in de praktijk. Bohn Stafleu van Loghum; 2011. p. 26-73.

[16] Ursum J, Rijken M, Heijmans M, Cardol M, Schellevis F. Zorg voor mensen met een chronische ziekte: organisatie van zorg, zelfmanagement, zelfredzaamheid en participatie. Overzichtstudies. Utrecht: NIVEL; 2011116.

[17] Dilorio C, Bamps Y, Walker ER, Escoffery C. Results of a research study evaluating WebEase, an online epilepsy self-management program. Epilepsy Behav 2011;22: 469-74.

[18] Newman L, Biedrzycki K, Baum F. Digital technology use among disadvantaged Australians: implications for equitable consumer participation in digitally-mediated communication and information exchange with health services. Aust Health Rev 2012;36:125-9.

[19] Pramuka M, Hendrickson R, Van Cott AC. Survey results of internet and computer usage in veterans with epilepsy. Epilepsy Behav 2010;17:366-8.

[20] Norman C. eHealth literacy 2.0: problems and opportunities with an evolving concept. J Med Internet Res 2011;13, e125.

[21] van Deursen AJ, van Dijk JA. Internet skills performance tests: are people ready for eHealth? J Med Internet Res 2011;13, e35.

[22] US Centers for Disease Control and Prevention Epilepsy Program. Internet use and looking up information online in adults with epilepsy varies by epilepsy status-2013 national health interview survey. Epilepsy Behav 2016;54:47-9.

[23] Centraal Bureau voor de Statistiek. http://statline.cbs.nl/StatWeb/publication/? $\mathrm{VW}=\mathrm{T} \& \mathrm{DM}=\mathrm{SLnl} \& \mathrm{PA}=71098 \mathrm{ned} \& \mathrm{la}=\mathrm{nl}$. In: ICT gebruik van personen naar persoonskenmerken 2005-20013.

[24] Berner J, Rennemark M, Jogréus C, Anderberg P, Sköldunger A, Wahlberg M, et al. Factors influencing internet usage in older adults (65 years and above) living in rural and urban Sweden. Health Informatics J 2015;21(3):237-49. 